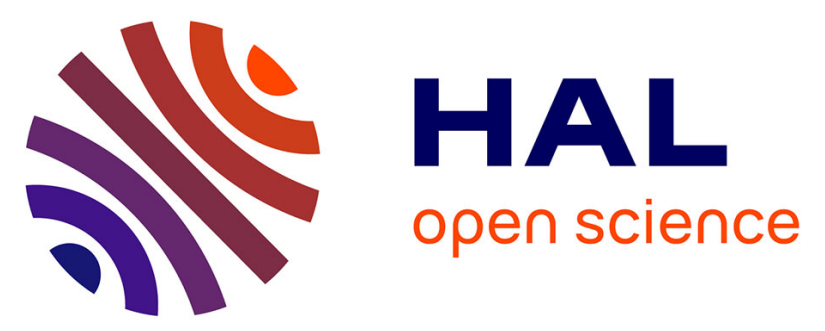

\title{
Characterization of the aquifers of the Bangui urban area, Central African Republic, as an alternative drinking water supply resource
}

Chantal-Laure Djebebe-Ndjiguim, Frédéric Huneau, A. Denis, E. Foto, G. Moloto-A-Kenguemba, Hélène Celle-Jeanton, E. Garel, Jessy J. Jaunat, J. Mabingui, Philippe Le Coustumer

\section{To cite this version:}

Chantal-Laure Djebebe-Ndjiguim, Frédéric Huneau, A. Denis, E. Foto, G. Moloto-A-Kenguemba, et al.. Characterization of the aquifers of the Bangui urban area, Central African Republic, as an alternative drinking water supply resource. Hydrological Sciences Journal, 2013, 58 (8), pp.1760-1778. 10.1080/02626667.2013.826358 . hal-01066869

\section{HAL Id: hal-01066869 https://hal.science/hal-01066869}

Submitted on 19 Nov 2021

HAL is a multi-disciplinary open access archive for the deposit and dissemination of scientific research documents, whether they are published or not. The documents may come from teaching and research institutions in France or abroad, or from public or private research centers.
L'archive ouverte pluridisciplinaire HAL, est destinée au dépôt et à la diffusion de documents scientifiques de niveau recherche, publiés ou non, émanant des établissements d'enseignement et de recherche français ou étrangers, des laboratoires publics ou privés.

\section{(ㅇ)(1) $\$$}

Distributed under a Creative Commons Attribution - NonCommerciall 4.0 International 


\title{
Characterization of the aquifers of the Bangui urban area, Central African Republic, as an alternative drinking water supply resource
}

\author{
C.L. Djebebe-Ndjiguim ${ }^{1,2,3}$, F. Huneau ${ }^{1,2}$, A. Denis ${ }^{4}$, E. Foto ${ }^{3}$, G. Moloto-a-Kenguemba ${ }^{3}$, \\ H. Celle-Jeanton ${ }^{5,6,7}$, E. Garel ${ }^{1,2}$, J. Jaunat ${ }^{8}$, J. Mabingui $^{3}$ and P. Le Coustumer ${ }^{8}$ \\ ${ }^{1}$ Faculté des Sciences et Techniques, Laboratoire d'Hydrogéologie, Université de Corse Pascal Paoli, Campus Grimaldi, BP 52, F-20250 \\ Corte, France \\ huneau@univ-corse.fr \\ ${ }^{2}$ CNRS, UMR 6134, SPE, F-20250 Corte, France \\ ${ }^{3}$ Faculté des Sciences, Laboratoire d'Hydrosciences Lavoisier (LHL), Université de Bangui, BP 908, Avenue des Matyrs, Bangui, \\ Central African Republic \\ ${ }^{4}$ Université de Bordeaux, UMR 5295 I2M - Génie Civil et Environnemental,F-33405 Talence, France \\ ${ }^{5}$ Laboratoire Magmas et Volcans, Clermont Université, Université Blaise Pascal,F-63038 Clermont-Ferrand, France \\ ${ }^{6}$ CNRS, UMR 6524, LMV,F-63038 Clermont-Ferrand, France \\ ${ }^{7}$ IRD, R 163, LMV,F-63038 Clermont-Ferrand, France \\ ${ }^{8}$ Géoressources \& Environnement, Université de Bordeaux, EA 4592,F-33607 Pessac, France
}

\begin{abstract}
This paper presents the results of a survey carried out in 2010 aimed at evaluating the type and quality of the groundwater resources of the Bangui region of the Central African Republic. This work is the first step towards the development of groundwater resources in the Central African Republic in order to find alternatives to direct pumping from the Ubangi River and provide the population of the suburbs with a safer drinking water supply from deep boreholes. By combining both geological and hydrogeochemical approaches, it appears that the geology of Bangui is favourable to the development of a secure and sustainable water supply from groundwater provided that the conditions of exploitation would be constrained by the local authorities. The deep Precambrian carbonate aquifers, known as the Bimbo and Fatima formations, are identified as target resources in view of the relatively good quality of their water from the chemical point of view, and the semi-confined structure of the aquifers that prevents the mixing with shallow aquifers that are already strongly affected by domestic and industrial pollution. The main difficulty in terms of exploitation is to appreciate the depth of the resource and the more or less fractured/palaeo-karstified type of the porosity.
\end{abstract}

Key words groundwater; hydrochemistry; hydrogeology; carbonate aquifer; drinking water supply; target resource; urban pollution; Central African Republic; Africa

\section{Caractérisation des aquifères de la région urbaine de Bangui comme ressource alternative en eau potable}

Résumé Cet article présente les résultats d'une étude réalisée en 2010 dans le but d'évaluer le type et la qualité des ressources en eaux souterraines de la région de Bangui. Ce travail se présente comme la première étape vers le développement des ressources en eaux souterraines en République Centrafricaine afin de trouver des alternatives au pompage direct des eaux de l'Oubangui et pour fournir à la population des banlieues une eau potable de meilleure qualité à partir de forages profonds. En combinant les deux approches géologique et hydrogéochimique, il apparaît que le sous-sol de Bangui est favorable au développement d'un approvisionnement en eau sécurisé et durable par les eaux souterraines sous réserve que les conditions d'exploitation soient règlementées par les 
autorités locales. Les aquifères profonds du Précambrien connus sous le nom de formations carbonatées de Bimbo et de Fatima sont identifiés comme ressources cibles, compte tenu de la relativement bonne qualité de l'eau du point de vue chimique et de la structure semi-captive des aquifères qui limite les mélanges avec les aquifères superfi-ciels déjà fortement touchés par les pollutions domestiques et industrielles. La principale difficulté en termes d'exploitation est d'apprécier la profondeur de la ressource et le caractère plus ou moins fracturé/paléo-karstifié de la porosité.

Mots clefs eau souterraine; hydrochimie; hydrogéologie; aquifère carbonaté; alimentation en eau potable; ressource cible; pollution urbaine; République Centrafricaine; Afrique

\section{INTRODUCTION}

The city of Bangui, the capital of the Central African Republic, is located on the right bank of the Ubangi River, which is the northernmost tributary of the Congo River. Since its foundation in 1889 , this city has suffered from serious problems of water management. This is related to the specifics of the city's location (steep hills surrounding a large, flat, poorlydrained, swampy valley) and to the urbanization process responsible for reducing the area of permeable soils, and the associated increased runoff processes under tropical rainfall conditions. It is a paradox that, although surface waters are abundant in the region, important limitations concerning the drinking water supply have appeared for the last two decades (Nguimalet 2004). As a consequence, a clean and safe drinking water supply is not available to the majority of the population of Bangui. Tap water is only delivered in the very centre of the city for just about $20 \%$ of the population (Nguimalet 2004), leaving the vast majority of the informal/spontaneous settlements of the suburbs with no piped supply, and so water is tapped from groundwater via shallow hand-dug wells. The marked increase in the urban area of Bangui, associated with a population explosion and immigration from the rural regions of the Central African Republic, have forced the population to dig more and shallower wells and to use potentially harmful water to meet their needs (Doyemet 2006). This is particularly worrying for the official authorities in charge of health, given the quasi-absence of sewage systems over the whole Bangui area, and the low income of the urban poor population.

Such informal settlements are very common in many big cities of the developing countries of Africa, South America and Asia (de Waele et al. 2004, Fantong et al. 2010, Fouépé Takounjou et al. 2010, Rakhmatullaev et al. 2010, Foster et al. 2011). SubSaharan Africa has the highest proportion of urban population living in informal settlements (Takem et al. 2010), which is about $80 \%$. Estimates from Tanawa et al. (2002) and Cronin et al. (2006) demonstrate that, in such informal settlements, more than $80 \%$ of the suburban population in developing countries uses groundwater for drinking purposes. In such a context, groundwater quality is a matter of great concern given the ever-growing population and the large amount of waste produced compared to the limited facilities for waste disposal. The city of Bangui experiences such problems and is therefore an interesting case study for Africa.

This paper presents the results of a preliminary hydrochemical survey carried out in April 2010 aimed at evaluating the chemical quality of the groundwater of the Bangui region. This work is the first step towards a more comprehensive approach to the development of groundwater resources in the Central African Republic aiming to find alternatives to direct pumping in the Ubangi River and provide the population of the suburbs with safer drinking water supply from deep boreholes.

\section{STUDY AREA}

\subsection{General setting}

The Central African Republic is a landlocked country in the heart of Africa with a land area of about $622000 \mathrm{~km}^{2}$. With a population of about 4 million, the population density is low (6.5 inhabitants $/ \mathrm{km}^{2}$ ). The capital city Bangui, with an estimated population of around 800000 inhabitants in 2003 (Nguimalet 2004), lies on the north bank of the Ubangi River (Fig. 1) in Ombella-M'Poko Province.

The spatial extent of the city has increased markedly since the beginning of the 19th century, from $2.12 \mathrm{~km}^{2}$ in 1912 to $22.56 \mathrm{~km}^{2}$ in the $1960 \mathrm{~s}$, and more than $80 \mathrm{~km}^{2}$ today. This growth is linked to both the demographic explosion, as in most regions of West and Central Africa, and to an intense rural flight, but also to immigration.

The study area (latitude: $4^{\circ} 20^{\prime}-4^{\circ} 30^{\prime} \mathrm{N}$; longitude: $18^{\circ} 30^{\prime}-18^{\circ} 45^{\prime}$ E) covers not only the city centre, but also the vast suburbs developing along the Ubangi River and north along the main road. 


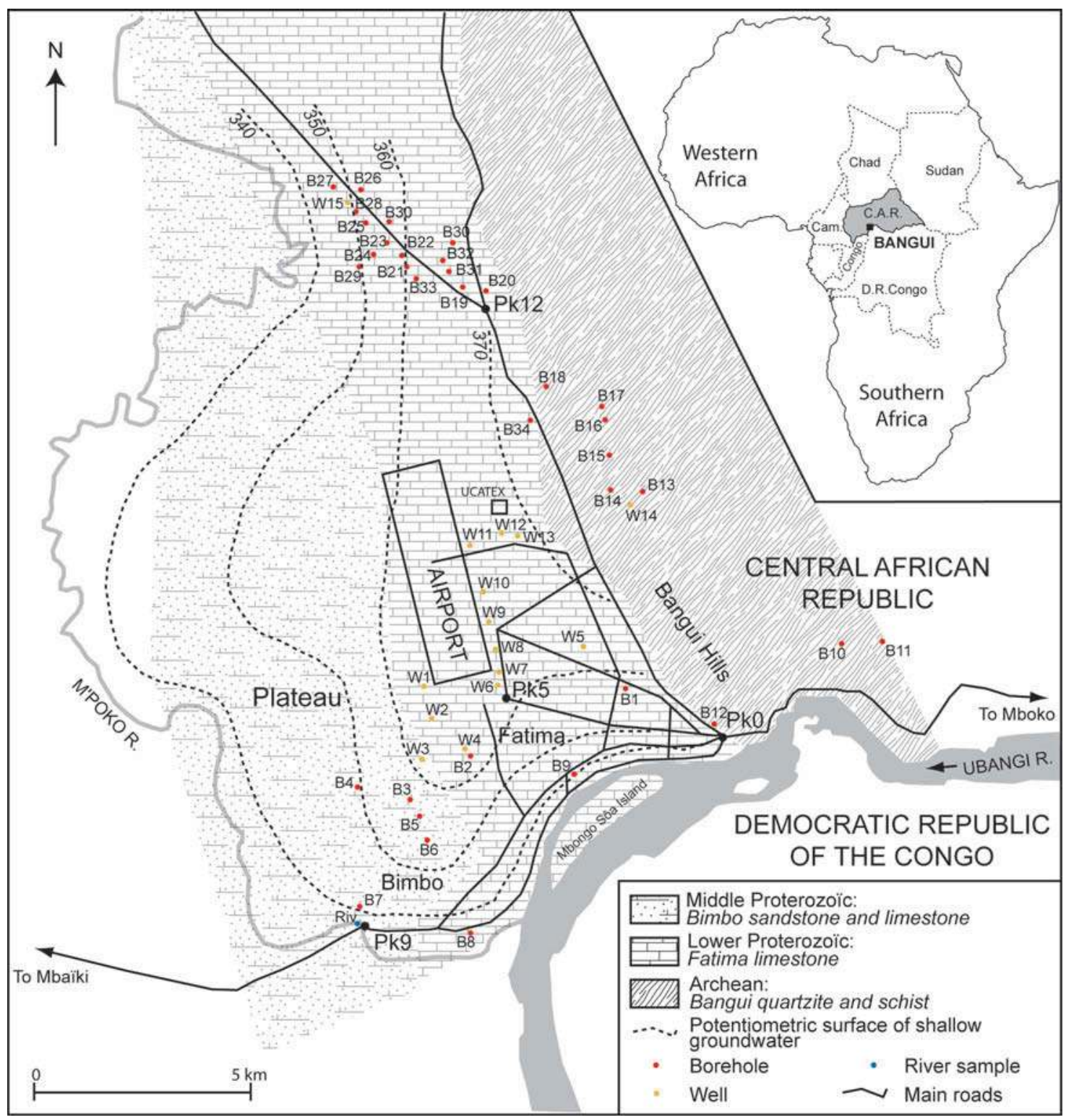

Fig. 1 Location of the study area, simplified geological map of the Precambrian hard-rock terrain, schematic potentiometric surface of the shallow aquifer (adapted from Japan International Cooperation Agency, JICA 1999), groundwater and river water sampling points. Tertiary sediments covering the area are not shown to improve the clarity of the illustration.

The suburban areas of Bangui city are mainly composed of informal settlements deprived of any water supply or sewage network. The national company in charge of water supply, SODECA, is only in a position to deliver treated tap water in the very central part of Bangui and in a few peripheral quarters. The delivered water is pumped from the Ubangi River and treated mainly to decrease the turbidity, and directly chlorinated to guarantee its disinfection to the consumers. The percentage of inhabitants with access to the treated drinking water was $44 \%$ in 2006 (Doyemet 2006).

\subsection{Geomorphology of the area}

From the physiographic point of view, the Bangui region is composed of a relatively flat alluvial plain at 340-360 $\mathrm{m}$ a.s.1. altitude, bordered by the Ubangi River to the southeast. This plain is very sensitive to flooding, particularly during the rainy season (Boulvert 1996). To the east lie the Bangui hills, 500-600 m a.s.l. in altitude and covered by a dense primitive tropical forest, which is protected. To the west is a vast plateau, with an undulating surface at an altitude varying from 360 to $400 \mathrm{~m}$ a.s.l. This plateau 
is cut by small canyons and is locally affected by topographic depressions; it is crossed from the north to the south by the M'Poko River and covered by the remaining tropical forest, or increasing agricultural activities. The extent of the city over the plateau area increases every year.

\subsection{Hydrological setting and hydro-climatological conditions}

Bangui is characterized by a tropical savannah climate with a rainy season from April to October and dry season from November to March (Callede and Arquisou 1972, Riou 1972). The average rainfall amount is around $1500 \mathrm{~mm}$ per year (Table 1). The maximum temperature $\left(>31^{\circ} \mathrm{C}\right)$ is recorded in March and the coolest $\left(24-25^{\circ} \mathrm{C}\right)$ in December. The atmospheric humidity is always at least $60 \%$, with values of $80-85 \%$ between June and November. Evapotranspiration has been estimated at around $1200 \mathrm{~mm} \mathrm{year}^{-1}$ at the Bangui-Orstom station for the period 1951-1989, and the effective infiltration at about $300 \mathrm{~mm}_{\text {year }}{ }^{-1}$ (Nguimalet 2004).

In terms of vegetation and soil type, the Bangui region appears as a transition zone between the tropical humid forest and the savannah forest (Boulvert 1976), lying at the northernmost boundary of the great Congo forest. Due to the development of the city, the natural vegetation is quickly degrading, resulting in the degradation and erosion of the soils. The soil type is mostly ferralitic, as a result of chemical weathering and accumulation of humus beneath the forest vegetation, accompanied by decomposition of most of the primary minerals, except quartz, and accumulation of secondary minerals, such as kaolinite, goethite and gibbsite. These typically have a low silica content and a high content of aluminium and iron.

The hydrographic network of the Bangui region is composed of the Ubangi River, which is the largest right-bank tributary of the Congo River of Central Africa (Dupré et al. 1996, Runge and Nguimalet 2005), and the M'Poko River draining the north of the Bangui region and joining the Ubangi River in the southwest of the study area. A few small streams, more or less perennial and sometimes partially canalized, occur over the city region and discharge into the M'Poko or the Ubangi rivers.

\subsection{Geological setting}

The geology of the Bangui region is very complex; hard-rock formations dated from the Precambrian are covered by surface formations of Tertiary and Quaternary age. The region shows intense faulting and folding features organized along three main directions, $\mathrm{N} 10^{\circ}-\mathrm{N} 30^{\circ}, \mathrm{N} 60^{\circ}-\mathrm{N} 80^{\circ}$ and $\mathrm{N} 130^{\circ}-\mathrm{N} 150^{\circ}$ (Wacrenier 1960, Mestraud 1982, Poidevin 1976, Cornachia and Giorgi 1986, Doyemet 2006). Only one major folding phase is observed, corresponding to an $\mathrm{E}-\mathrm{W}$ to $\mathrm{SE}-\mathrm{NW}$ compression. These major discontinuities tend to create a relative compartmentalization of the geology.

Based on the observations made by Poidevin (1976, 1996, 2007), Cornacchia and Giorgi (1986), Alvarez (1995, 1997), Rolin (1992) and JICA (1999), four major Precambrian lithostratigraphic units can be described in the region of Bangui:

- the Bimbo series (Middle Proterozoic) of sandstone, limestone, pelites and black quartzite conglomerate, about $120 \mathrm{~m}$ thick with a dip of $50-70^{\circ}$ of $\mathrm{N} 70^{\circ}$ direction;

- the Fatima series (Lower Proterozoic) of grey to black limestone, calcareous schist and marginally dolomite, of thickness locally reaching $300 \mathrm{~m}$;

- the Bangui-M'baïki-Boali series (Archean) of sandstone, quartzite and locally argillite and conglomerate of about $300 \mathrm{~m}$ thickness; and

- the Yangana-Pama-Boda series (Archean) of quartzite and schist.

These series are not conformably superposed and series may be missing due to the intricate tectonics of the region (Doyemet 2006). The relative chronology and the exact dating and sequence of these Precambrian formations is still questioned and the object of strong controversy. Detailed comments on

Table 1 Monthly and annual average air temperature, rainfall amount and atmospheric humidity for the Bangui airport ASECNA station, data on the 1994-2005 period (after Doyemet 2006).

\begin{tabular}{|c|c|c|c|c|c|c|c|c|c|c|c|c|c|}
\hline & Jan & $\mathrm{Feb}$ & Mar & Apr & May & Jun & Jul & Aug & Sep & Oct & Nov & Dec & Year \\
\hline Temperature $\left({ }^{\circ} \mathrm{C}\right)$ & 25.0 & 26.2 & 31.1 & 30.0 & 28.5 & 27. & 26.7 & 28.8 & 27.0 & 26.7 & 26.5 & 24.8 & 27.4 \\
\hline Rainfall (mm) & 12.0 & 33.4 & 81.9 & 111.5 & 141.4 & 197.6 & 177.5 & 230.0 & 206.8 & 218.1 & 69.7 & 24.3 & 1504.2 \\
\hline Humidity (\%) & 69.4 & 63.9 & 70.3 & 76.8 & 79.6 & 83.7 & 85.4 & 85.1 & 84.2 & 84.6 & 81.5 & 76.1 & 78.4 \\
\hline
\end{tabular}


this topic and the alternative options are presented and discussed by Nguimalet (2004) and Doyemet (2006).

Over the Bangui city area, two sectors can be distinguished from both the morphology and lithology points of view:

- the Bimbo-Bangui sector in the west, composed mostly of carbonate rocks and conglomerates, but with very few outcrops of the Bimbo limestone and sandstone or Fatima limestone (Fig. 1); and

- the eastern sector forming the hills of Bangui, composed of quartzite associated with schist, micaschist and amphibolites, with garnet outcropping in the northeast, and corresponding to the Yangana series.

The surface formations cover the Precambrian substratum unconformably. The Tertiary formations are made of clay, sandstone and conglomerate and are more or less consolidated. At the surface, these formations tend to be entirely transformed into lateritic clays of rusty-red colour, argillaceous sand and clayey gravel under strong climatic alteration. The thickness of this formation varies greatly between 25 and $175 \mathrm{~m}$, depending on the palaeo-morphology and structure of the Precambrian formations. The Quaternary deposits, originating from past major floods in the Ubangi River, form a 1- to 4-mdeep layer of sandy loam, sand and gravel widely covering the alluvial plains and the Bangui city area.

2.4.1 Hydrogeological units According to Cornacchia et al. (1990) and Plesinger (1990), two main hydrogeological units can be distinguished in the region of Bangui: (i) the non-carbonate formations and (ii) the carbonate Precambrian formations.

The non-carbonate formations comprise the surface formations in which most of the urban wells tap the groundwater. These shallow formations can be of Tertiary, Quaternary (clay, sand, gravel) or even Precambrian age in the eastern hills of Bangui (quartzite, schist, gneiss). A few authors (JICA 1999) have proposed singling out another waterbearing level in the surface laterite layer, which is porous and slightly permeable in some places, but generally this very shallow aquifer is interspersed with the other non-carbonate formations and the groundwater is relatively well connected hydraulically.

The Precambrian carbonate formations mainly composed of limestone with dolomitic layers and even sandstone with calcareous cement, lying at a few tens of metres depth, are principally exploited through boreholes equipped with hand pumps (DjebebeNdjiguim 2007). It is important to note that these carbonate formations do not outcrop in the Bangui region and are only known of by drilling. Two types of carbonate rock are distinguished and are locally known as the Fatima limestone and the Bimbo limestone. An approximate delimitation of the area of these formations is proposed on Fig. 1, after the investigations and synthesis proposed by Doyemet (2006). As previously explained, the Precambrian carbonate formations are covered by Tertiary and Quaternary deposits and, hence, are difficult to describe, locate and differentiate and relatively little is known about them. However, they have previously been recognized as fractured and karstified in the geology of Bangui. This is the case in the vicinity of the airport where the drilling for the UCATEX factory encountered major karst conduits below a depth of $150 \mathrm{~m}$, and the CASTEL brewery borehole, close to Bimbo, reached fractured limestone at a depth of about $50 \mathrm{~m}$. At the wider scale, the plain of Bangui has numerous surface topographic depressions indicating the existence of crypto-karstic or pseudo-karstic features (Boulvert and Salomon 1988, Alvarez 1997, Boulvert and Juberthie 1998) reflecting the development of karstogenetic processes at depths below the Tertiary cover. These areas are often poorly drained and occupied by swamps. The inherited palaeo-morphology of the Precambrian carbonate formations is hence complex and efforts to tap the limestones of Fatima or Bimbo in the region of Bangui can fail due to the great variability of the hard-rock depth and the technical and financial limits of the local drillers. In the Bangui region, the limestone is reached at between $25 \mathrm{~m}$ and more than $200 \mathrm{~m}$ depth west of the airport (JICA 1999, Nguimalet 2004).

The Precambrian carbonate aquifer, covered by the more-or-less permeable Tertiary formations, cannot be considered as confined, but more as a semi-confined aquifer. This is due to the locally very clayey nature of the Tertiary sediments and confirmed by the slight over pressure of the carbonate groundwater compared to the shallow aquifer.

So, two aquifers have to be considered: a shallow one in the Tertiary non-carbonate sediments including the laterite groundwater, and a deep carbonate one lying at various depths under a discontinuous semi-permeable cover and showing karst and fracture features. 
2.4.2 Hydrogeological characteristics The shallow non-carbonate aquifer has a porous nature and a mean thickness of about $50 \mathrm{~m}$. In its most superficial part (laterite) it is poorly productive (JICA 1999) with a low permeability $\left(1.1 \times 10^{-6}\right.$ to $9.2 \times 10^{-6} \mathrm{~m} \mathrm{~s}^{-1}$ ) even in the most sandy lenses. In favourable situations the Precambrian noncarbonate formations are able to produce up to $20 \mathrm{~m}^{3} \mathrm{~h}^{-1}$, and are sometimes used for the drinking water supply through boreholes and hand pumps, especially in the hilly surroundings of Bangui. Generally, these formations, and the Tertiary sedimentary formations, covering most of the Bangui area, are poorly permeable and exploited only through hand-dug wells of a few metres depth. These wells, deprived of any protection, are the main water supply of the informal settlements and suburbs of Bangui, and tap very low quality groundwater that is sensitive to all the surface influences of a fast developing African capital, such as the lack of waste management, the absence of a sewage system and the presence of numerous pit latrines (Elbaz-Poulichet et al. 2002, Lutz et al. 2009, Nikiema et al. 2010, Huneau et al. 2011). The piezometric level is usually encountered, depending on the season, at a depth of $1-5 \mathrm{~m}$. The annual water table fluctuation is between 2 and $5 \mathrm{~m}$, with high waters in October and low waters in April-May. At the bottom of the Tertiary sediments lies a more or less continuous layer of lacustrine clay which acts as a low permeability interface with the underlying Precambrian carbonate aquifer. Based on the observations of JICA (1999), the morphology of the water table follows the topography, and the groundwater flow direction is mostly oriented from the northeast to the southwest and south where groundwater is in equilibrium with the Ubangi River pressure potential (Fig. 1).

The deep Precambrian carbonate aquifer can be considered as the most important groundwater reservoir of the region. Its hydrogeological properties are favourable to exploitation given its permeability of $2.3 \times 10^{-3}$ to $9.3 \times 10^{-5} \mathrm{~m} \mathrm{~s}^{-1}$ in boreholes where karst features or fractures were identified (JICA 1999). In boreholes tapping more compact limestone, permeability is lower: $1.0 \times 10^{-6}$ to $2.1 \times 10^{-7} \mathrm{~m} \mathrm{~s}^{-1}$ (JICA 1999), but still favourable to exploitation with hand pumps. The thickness of the carbonate formations is not known and the bottom has never been reached (Nguimalet 2004). The arrangement of hydraulic heads in the deep aquifer is more complex than in the shallow aquifer according to JICA (1999), and seems to be influenced by the structure of the Precambrian formations, especially the main $\mathrm{N}-\mathrm{S}$ trending faults under the Bangui region. However, the number of boreholes used to establish the groundwater flow map is very limited and it cannot be considered as reliable. Indeed, it is probable that the groundwater flow direction of the deep groundwater is also organized towards the Ubangi River and its tributaries which constitute the main drainage axis of the region, but it is also very likely that the pathways used are more complex because of the faulted and karstified structure of the aquifer.

Carbonate formations have been used by the "Ministère de l'Hydraulique" of the Central African Republic to develop a safe and secure alternative to shallow wells for the supply of water in the Bangui suburbs. The great difficulty arising from this attempt was linked to the variability of the depth of the Precambrian formations, to the lack of knowledge of the palaeo-morphology and palaeo-alteration of the carbonate rocks at depth, and to the technical limitations of local drillers who might not have the capacity to drill to more than 100-120 m depth.

\section{GROUNDWATER SAMPLING AND ANALYTICAL METHODOLOGY}

A selection of 50 sampling points was made to represent the whole region of Bangui city. In April 2010, 34 boreholes, 15 wells and the M'Poko River water were sampled. All the sampling points are regularlyused wells or boreholes. These wells/boreholes are intended to tap the two main aquifers of the region. At each site, information was collected regarding all human activities and practices in the vicinity that could be potential sources of pollution. These included dish washing, presence of pit latrines in close proximity, presence of standing waste and/or waste dumping uphill of the sampling point, and former industrial activities.

In situ parameters were also measured at each site. Electrical conductivity (EC), temperature (T) and $\mathrm{pH}$ were measured using a WTW 340i multimeter, and $\mathrm{HCO}_{3}{ }^{-}$was determined in the field using an $\mathrm{HACH}$ digital titrimeter. Samples were filtered through $0.45-\mu \mathrm{m}$ membranes and were collected for major element analysis in polyethylene bottles. The aliquot for cation analysis was acidified to $\mathrm{pH}<2$ with $1 \% \mathrm{v} / \mathrm{v} \mathrm{HNO}_{3}$. Samples were stored at $4{ }^{\circ} \mathrm{C}$ in the "Laboratoire d'Hydrosciences Lavoisier" of the University of Bangui before fast shipment to the 
EGID Institute of the University of Bordeaux, in France.

Major ions were determined by HPLC using a Dionex 320 chromatograph (IonPac CS16) for the cations and a Dionex 1100 chromatograph (IonPac AS11-HC) for the anions. The quality of the chemical analysis was checked using an electro-neutrality condition up to $5 \%$.

The calcite and dolomite saturation indexes as well as the $\mathrm{pCO}_{2}$ were calculated using the PHREEQC code (Parkhurst and Appelo 1999).

The sampling points were identified and numbered according to the type of the water extraction device: cased borehole equipped with hand pump (B) or ordinary well without casing (W). Figure 2 illustrates the different types of boreholes and wells sampled during this campaign.

Due to the lack of any national registry of boreholes used for drinking water supply, it was not possible to access lithostratigraphic or depth information for the boreholes. Thus, the boreholes cannot be considered to tap only the carbonate formations, but may also tap the Tertiary deposits in some places and sometimes even both aquifer levels. The wells, of only a few metres depth, are generally exclusively tapping the Tertiary levels or the laterite formation.

\section{RESULTS}

The results of the in situ parameter measurements and of the chemical analyses plus the ionic balance (IB) calculations for each analysis are displayed in Table 2 with the name, coordinates, altitude and sampling date of the points.

\subsection{Physicochemical parameters}

The groundwater temperature is between $25^{\circ}$ and $28^{\circ} \mathrm{C}$ for both wells and boreholes, a range close to the annual mean air temperature in the Bangui region of around $27^{\circ} \mathrm{C}$ (Table 1 ).

The $\mathrm{pH}$ of the wells tapping the shallow groundwater is acidic and ranges between 4.9 and 6.4 , as expected considering the clayey, siliceous and non-carbonate nature of the aquifer matrix. For the boreholes mostly tapping the Precambrian carbonate aquifer, the $\mathrm{pH}$ values are generally higher and around neutral. A few boreholes exhibit low $\mathrm{pH}$ values and probably tap only the Tertiary shallow aquifer without any interactions with the deep one. Intermediate $\mathrm{pH}$ values can be observed in the case of boreholes tapping both aquifer levels and thus providing mixed groundwater. The M'Poko River has a $\mathrm{pH}$ of 7.5 .

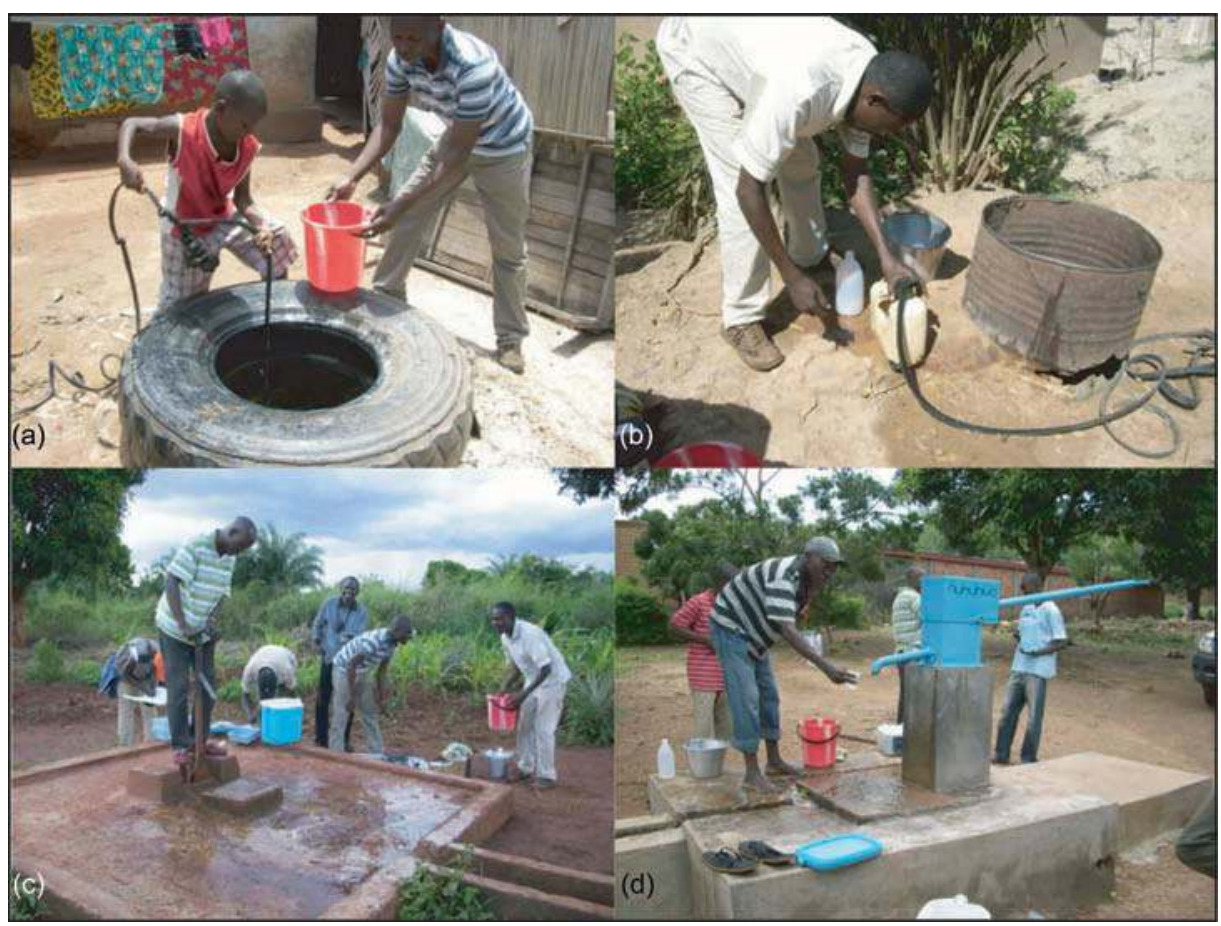

Fig. 2 Examples of the most common groundwater extraction devices and structures in the Bangui region: (a) shallow handdug well with a used tyre as a curb; (b) shallow hand-dug well with a corroded steel barrel as a curb; (c) borehole equipped with a foot pump and protected by a concrete slab; and (d) borehole equipped with a hand pump. 


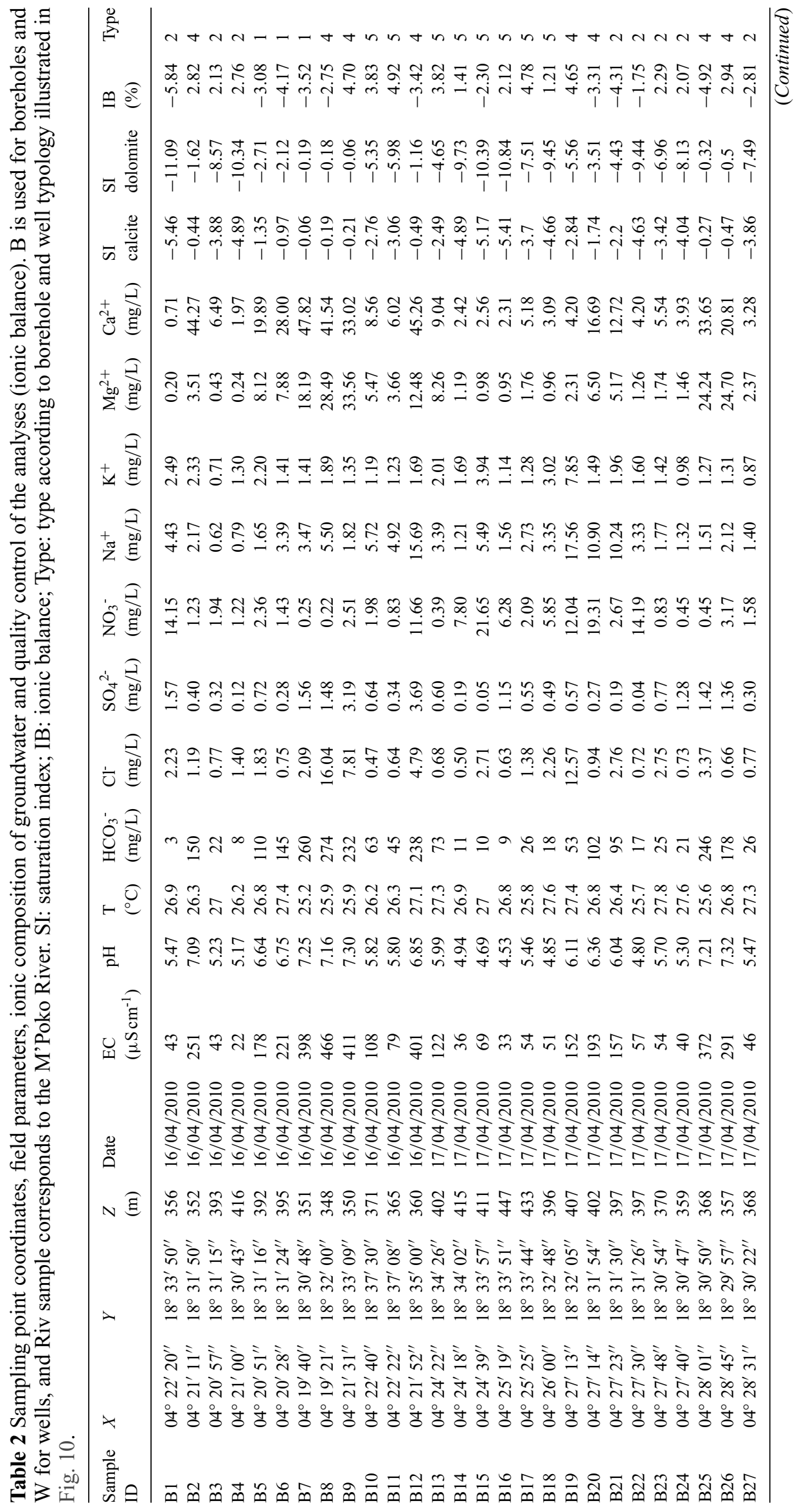




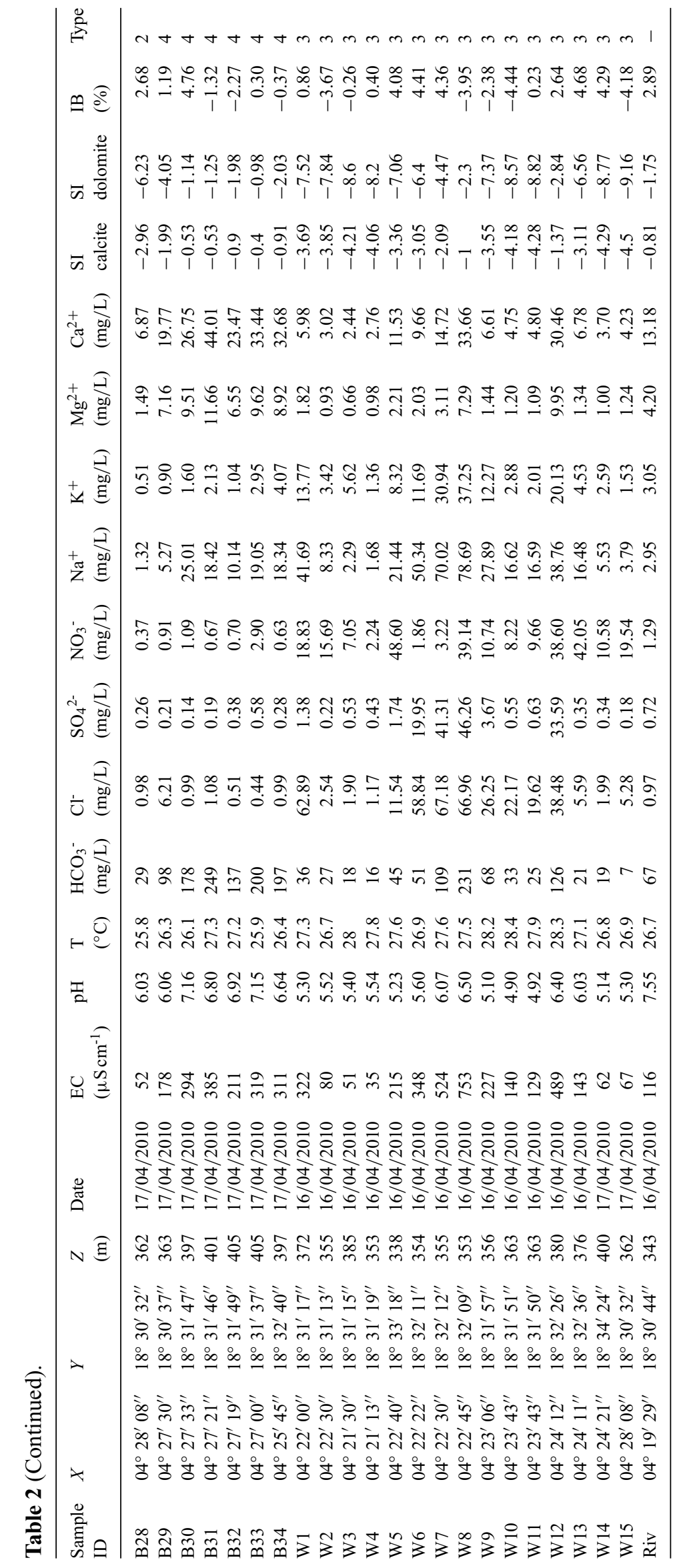


Electrical conductivity (EC) shows a wide range of values, from 22 to $753 \mu \mathrm{S} \mathrm{cm}^{-1}$. Generally the boreholes tend to show higher mineralization compared to the wells but with a high variability. The EC allows discrimination of two end members in the data set, one with high EC values, around $300-400 \mu \mathrm{S} \mathrm{cm}^{-1}$, corresponding to the carbonate aquifer groundwater, and a second with low values, $<150 \mu \mathrm{S} \mathrm{cm}^{-1}$, corresponding to the shallow groundwater. Intermediate values can be explained by mixing processes. The highest value of $753 \mu \mathrm{S} \mathrm{cm}^{-1}$ for W8 cannot be explained by the carbonate nature of aquifer matrix and is linked to anthropogenic influences.

\subsection{Major ions}

Bicarbonate ion $\left(\mathrm{HCO}_{3}{ }^{-}\right)$concentrations show wide variation, between 3 and $274 \mathrm{mg} / \mathrm{L}$. Groundwater samples from boreholes tend to be more concentrated than well groundwater samples, for which concentrations are very low $(<70 \mathrm{mg} / \mathrm{L})$, apart from $\mathrm{W} 7$, $\mathrm{W} 8$ and $\mathrm{W} 12$. The $\mathrm{Cl}^{-}$varies from 0.4 to $67 \mathrm{mg} / \mathrm{L}$, with low values for the borehole samples (average of $2.5 \mathrm{mg} / \mathrm{L}$ ) and relatively high concentrations in wells (average of $26.2 \mathrm{mg} / \mathrm{L}$ ). Concentrations of $\mathrm{SO}_{4}{ }^{2-}$ remain very low $(<3.7 \mathrm{mg} / \mathrm{L})$ in the boreholes. In the wells, concentrations are also generally low, but some high values are found, reaching $46 \mathrm{mg} / \mathrm{L}$ for W6, W7, $\mathrm{W} 8$ and $\mathrm{W} 12$. The $\mathrm{NO}_{3}{ }^{-}$concentrations are also relatively low for boreholes, reaching $10-20 \mathrm{mg} / \mathrm{L}$ for $\mathrm{B} 1, \mathrm{~B} 12, \mathrm{~B} 19, \mathrm{~B} 20$ and $\mathrm{B} 22$. For the wells, $\mathrm{NO}_{3}{ }^{-}$is present in half of the samples at concentrations to $10 \mathrm{mg} / \mathrm{L}$, and reaching $48 \mathrm{mg} / \mathrm{L}$ for W5.

The $\mathrm{Na}^{+}$concentrations vary between 0.6 and $78 \mathrm{mg} / \mathrm{L}$. For most of the boreholes, $\mathrm{Na}^{+}$concentrations are under $5-6 \mathrm{mg} / \mathrm{L}$, but some samples (B12, B19-B21, B30-B34) show values of $10-25 \mathrm{mg} / \mathrm{L}$ that are associated with high EC values. Concentrations of $\mathrm{K}^{+}$vary between 0.7 and $37 \mathrm{mg} / \mathrm{L}$. Borehole $\mathrm{K}^{+}$concentrations are relatively low, about a few mg/L, apart for B19 $(7.8 \mathrm{mg} / \mathrm{L})$. For the wells, concentrations in $\mathrm{K}^{+}$are relatively high in most of the samples and can exceed $20 \mathrm{mg} / \mathrm{L}$, especially at $\mathrm{W} 7, \mathrm{~W} 8$ and $\mathrm{W} 12$. These high $\mathrm{K}^{+}$concentrations are also associated with high $\mathrm{EC}$ values. Variations in $\mathrm{Mg}^{2+}$ and $\mathrm{Ca}^{2+}$ concentrations parallel one another, with values of $0.2-37 \mathrm{mg} / \mathrm{L}$ and $0.7-47 \mathrm{mg} / \mathrm{L}$, respectively. In the boreholes, $\mathrm{Mg}^{2+}$ and $\mathrm{Ca}^{2+}$ concentrations tend to show higher concentrations compared to the wells, for which only W8 and W12 can be distinguished.

\subsection{Piper diagram}

To comment on the chemical evolution and to define the chemical types of the Bangui groundwater, a Piper diagram displaying the results of the sampling campaign is featured in Fig. 3. Two major water types can be identified: (i) $\mathrm{Ca}^{2+}-\mathrm{Mg}^{2+}-\mathrm{HCO}_{3}{ }^{-}$water type corresponding mainly to the borehole groundwater, and to the M'Poko River, and (ii) $\mathrm{Cl}^{-}-\mathrm{NO}_{3}{ }^{-}-\mathrm{Na}^{+}-\mathrm{K}^{+}$water type corresponding to the well groundwater. This latter group shows some dispersion around the $\mathrm{Cl}^{-}-\mathrm{Na}^{+}$ water type zone with some outliers bordering the limit or the domain definition (W2, W3, W12, W14, W15, W9). A few boreholes (B1, B15, B19) also appear in the $\mathrm{Cl}^{-}-\mathrm{Na}^{+}$water type zone, with a tendency towards the $\mathrm{Na}^{+}-\mathrm{K}^{+}-\mathrm{HCO}_{3}^{-}$water type zone, and correspond to shallow boreholes and low mineralized groundwaters. The Piper diagram does not show display of the intensity of the mineralization of groundwater and just indicates the ratios between the different ionic species; therefore, it was interesting to use another graphic tool to illustrate the contrast observed between the different samples.

\subsection{Stiff diagrams}

The Stiff diagrams drawn from the data set are displayed in Figs 4 and 5 for boreholes and wells, respectively. The diagrams show that the samples can be divided into three groups, corresponding to: (i) mineralized groundwaters produced mostly from the boreholes and belonging to the $\mathrm{Ca}^{2+}$ $\mathrm{Mg}^{2+}-\mathrm{HCO}_{3}-$ water type, (ii) moderately mineralized groundwaters produced by a few boreholes and mostly coming from the wells showing intermediate water types between $\mathrm{Ca}^{2+}-\mathrm{HCO}_{3}{ }^{-}$and $\mathrm{Na}^{+}-\mathrm{Cl}^{-}$, and (iii) poorly mineralized groundwaters tapped from the wells and clearly of $\mathrm{Na}^{+}-\mathrm{Cl}^{-}$water type.

\section{DISCUSSION}

As previously explained, two main hydrogeological units can be described in the Bangui region. The results of this survey tend to confirm this assumption, and illustrate the main hydrochemical features of the associated aquifers. As displayed in Table 3, different correlations can be identified in the data set related mainly to the carbonate or non-carbonate type of the aquifers, but also to the strong anthropogenic influences that can affect groundwater flow in this urban region. 


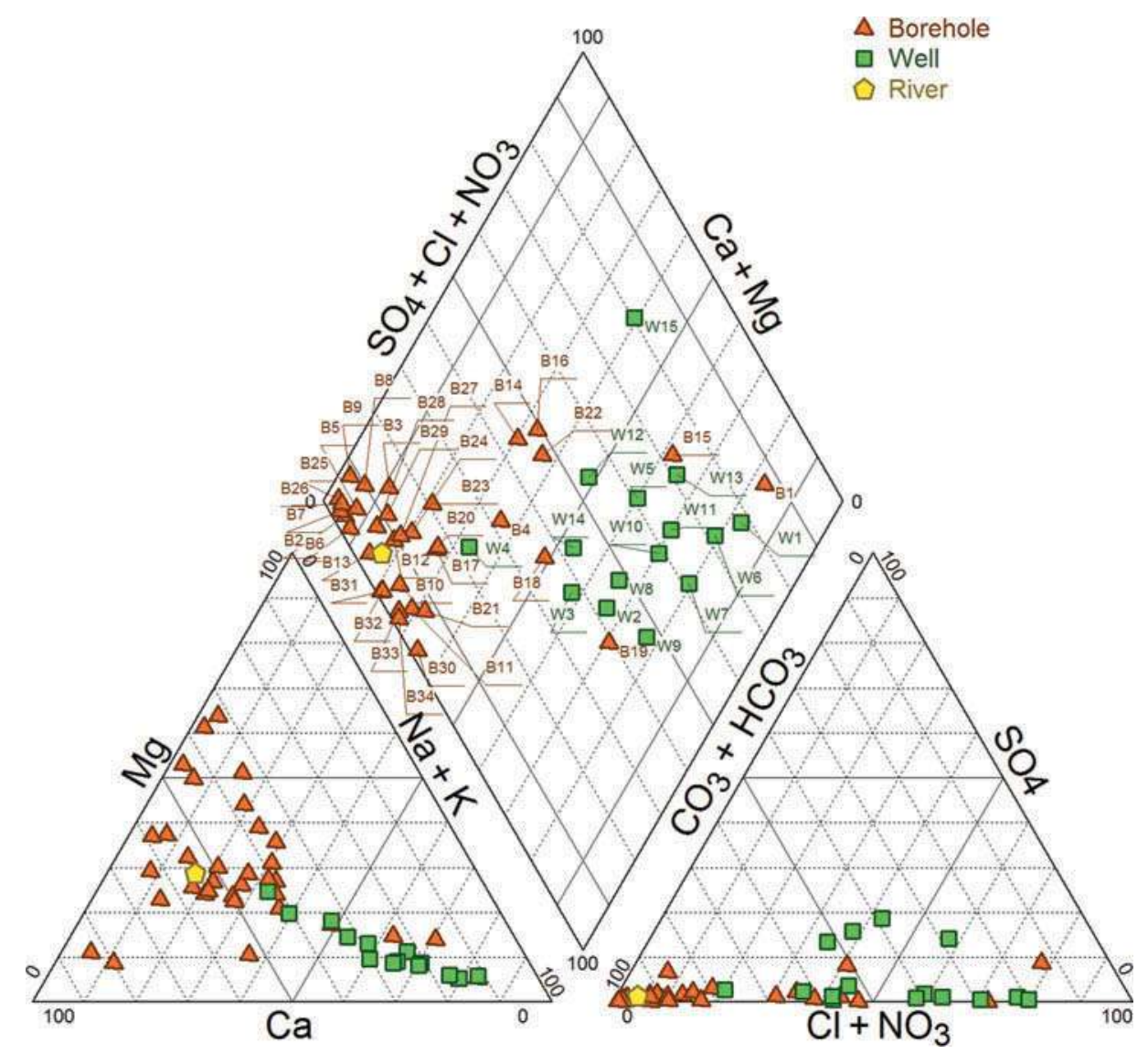

Fig. 3 Piper diagram showing the different water types of Bangui groundwaters tapped from wells and boreholes, and the M'Poko River water.

\subsection{Carbonate hydrolysis, carbon dioxide and groundwaters of deep origin}

The EC presents a large span of variation and is very significantly correlated to the bicarbonate concentrations. Figure 6 shows in detail the quality of the correlations for the wells and boreholes. Two tendencies are very clearly identified for $\mathrm{EC}>150$ $\mu \mathrm{S} \mathrm{cm}^{-1}$. The wells exhibit EC maximum values of more than $700 \mu \mathrm{S} \mathrm{cm}^{-1}$, and maximum concentrations in bicarbonate of about $250 \mathrm{mg} / \mathrm{L}$. The correlation for boreholes is stronger $(r=0.99)$ for lower EC values (maximum $466 \mu \mathrm{S} \mathrm{cm}^{-1}$ ) and slightly lower bicarbonate concentrations (maximum $274 \mathrm{mg} / \mathrm{L}$ ). This reveals and confirms the existence of two separated aquifers, a superficial one in the lateritic formations and another deeper one tapped only by the boreholes, with water of clearly carbonate nature and very sensitive to hydrolysis, as shown by the high bicarbonate concentrations and $\mathrm{pH}$ values close to neutrality or greater than 7. Calculated saturation indexes (Table 2 and Fig. 7), displaying the relationship of $\log \mathrm{pCO}_{2}$ versus $\mathrm{pH}$ of groundwater, confirm this observation. For both wells and boreholes, a decrease in $\mathrm{pH}$ is observed for increasing $\log \mathrm{pCO}_{2}$ values. For the wells, the $\log \mathrm{pCO}_{2}$ values remain above $10^{-1.5}$ bar, corresponding to relatively open system conditions (Appelo and Postma 2005, Chidambaram et al. 2011). This is in agreement with the shallowness of the laterite and Tertiary deposits aquifer. This is also the case for the boreholes exhibiting $\mathrm{pH}<6.5$. For boreholes with $\mathrm{pH} \geq 7$, an evolution towards closed system conditions is noted. These boreholes are also the ones tapping the deep carbonate aquifer below the Tertiary and Quaternary formations, and are disconnected from direct recharge from the surface waters.

Table 3 indicates strong statistical dependency between the other components of the carbonate equilibria, i.e. bicarbonate, calcium and magnesium. Figure 8 displays the form of the calcium and magnesium versus bicarbonate concentrations. In both graphs, the calcium and magnesium concentrations follow the same tendency, corresponding mainly to a progressive hydrolysis of the deep aquifer matrix that increases with the residence time of groundwater 



Fig. 4 Stiff diagram displaying the mineralization of Bangui groundwaters tapped from boreholes. Samples with identical profiles have been skipped: B4 and B16 identical to B14; B15 identical to B1; B11 and B13 identical to B10; B18, B22, $\mathrm{B} 24, \mathrm{~B} 27$ and B28 identical to B23.

within the carbonate aquifer (Celle-Jeanton et al. 2009, Jirakova et al. 2009, 2010). The relatively high content of magnesium also confirms the presence of dolomite in the carbonates composing the Bimbo and Fatima limestones. For most of the wells tapping the non-carbonate formations and some of the boreholes, the concentrations remain low $(<10 \mathrm{mg} / \mathrm{L}$ for $\mathrm{Ca}^{2+}, 5 \mathrm{mg} / \mathrm{L}$ for $\mathrm{Mg}^{2+}$ and $50 \mathrm{mg} / \mathrm{L}$ for $\mathrm{HCO}_{3}{ }^{-}$), but for bicarbonate concentrations $>100 \mathrm{mg} / \mathrm{L}$, the correlation is very clear, especially with calcium, and mainly relates to boreholes that are tapping the deep limestone aquifer. A few wells, W7, W8 and W12, show the same tendency, which is discussed in Section 5.3.

\subsection{Traces of anthropogenic influences and threats to the shallow aquifer}

Anthropogenic activities, such as the washing of clothes and kitchen utensils, and the dumping of 

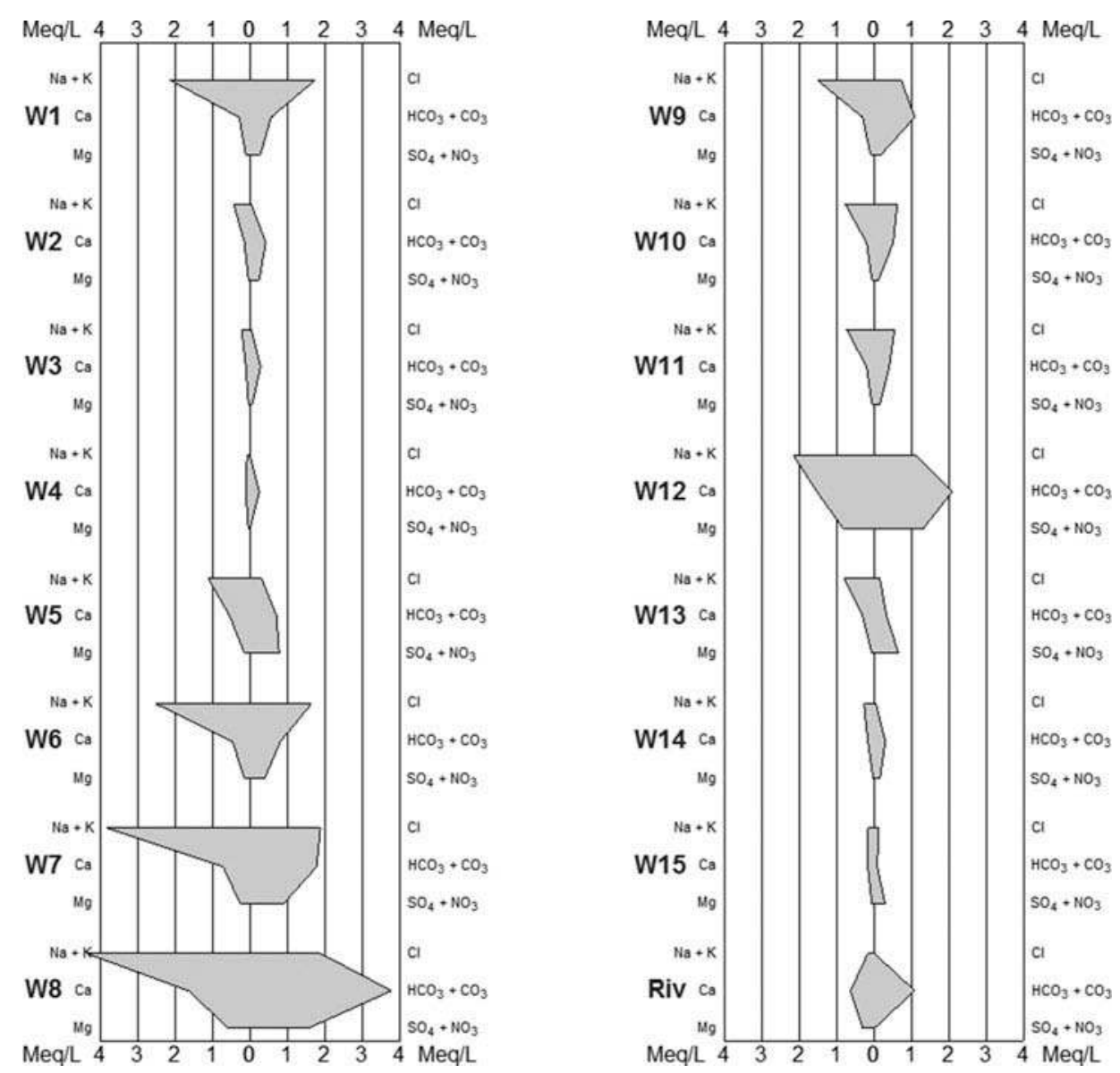

Fig. 5 Stiff diagram displaying the mineralization of Bangui groundwaters tapped from wells and the M'Poko River (Riv).

Table 3 Correlation matrix of the physico-chemical parameters and major ions from wells and boreholes of the Bangui region. Bold indicates correlation $r>50 \%$.

\begin{tabular}{|c|c|c|c|c|c|c|c|c|c|c|c|}
\hline & EC & $\mathrm{pH}$ & $\mathrm{T}$ & $\mathrm{HCO}_{3}^{-}$ & $\mathrm{Cl}^{-}$ & $\mathrm{SO}_{4}{ }^{2-}$ & $\mathrm{NO}_{3}^{-}$ & $\mathrm{Na}^{+}$ & $\mathrm{K}^{+}$ & $\mathrm{Mg}^{2+}$ & $\mathrm{Ca}^{2+}$ \\
\hline EC & 1 & 0.62 & -0.04 & 0.82 & 0.62 & 0.68 & 0.21 & 0.71 & 0.65 & 0.60 & 0.77 \\
\hline $\mathrm{pH}$ & & 1 & -0.39 & 0.84 & -0.07 & 0.10 & -0.23 & 0.06 & 0.01 & 0.74 & 0.83 \\
\hline $\mathrm{T}$ & & & 1 & -0.35 & 0.36 & 0.29 & 0.36 & 0.33 & 0.38 & -0.42 & -0.33 \\
\hline $\mathrm{HCO}_{3}^{-}$ & & & & 1 & 0.09 & 0.22 & -0.15 & 0.22 & 0.14 & 0.83 & 0.95 \\
\hline $\mathrm{Cl}^{-}$ & & & & & 1 & 0.80 & 0.35 & 0.91 & 0.88 & -0.05 & 0.05 \\
\hline $\mathrm{SO}_{4}^{2-}$ & & & & & & 1 & 0.37 & 0.85 & 0.93 & 0.03 & 0.20 \\
\hline $\mathrm{NO}_{3}^{-}$ & & & & & & & 1 & 0.42 & 0.49 & -0.20 & -0.10 \\
\hline $\mathrm{Na}^{+}$ & & & & & & & & 1 & 0.92 & -0.06 & 0.18 \\
\hline $\mathrm{K}^{+}$ & & & & & & & & & 1 & -0.08 & 0.11 \\
\hline $\mathrm{Mg}^{2+}$ & & & & & & & & & & 1 & 0.72 \\
\hline $\mathrm{Ca}^{2+}$ & & & & & & & & & & & 1 \\
\hline
\end{tabular}

waste, as well as the pit latrines located in the vicinity of the wells and scattered densely across the Bangui area, appear to have an impact on the shallow aquifer. This influence is underlined by positive correlations in Table 3 between EC, sodium, potassium, nitrate and sulphate. Figure 9 displays the relationship of sodium and potassium to chloride concentrations. The chloride concentrations of the wells are very high and make chloride the dominant anion in several samples. Since there is no geological source of chloride in the region, the positive correlation with high concentrations of both sodium and potassium reveals the influence of pollution mainly linked to household wastewater and the use of domestic detergents (Reimann and de Caritat 1998, Jaunat et al. 2012) on the surface groundwater. The boreholes 


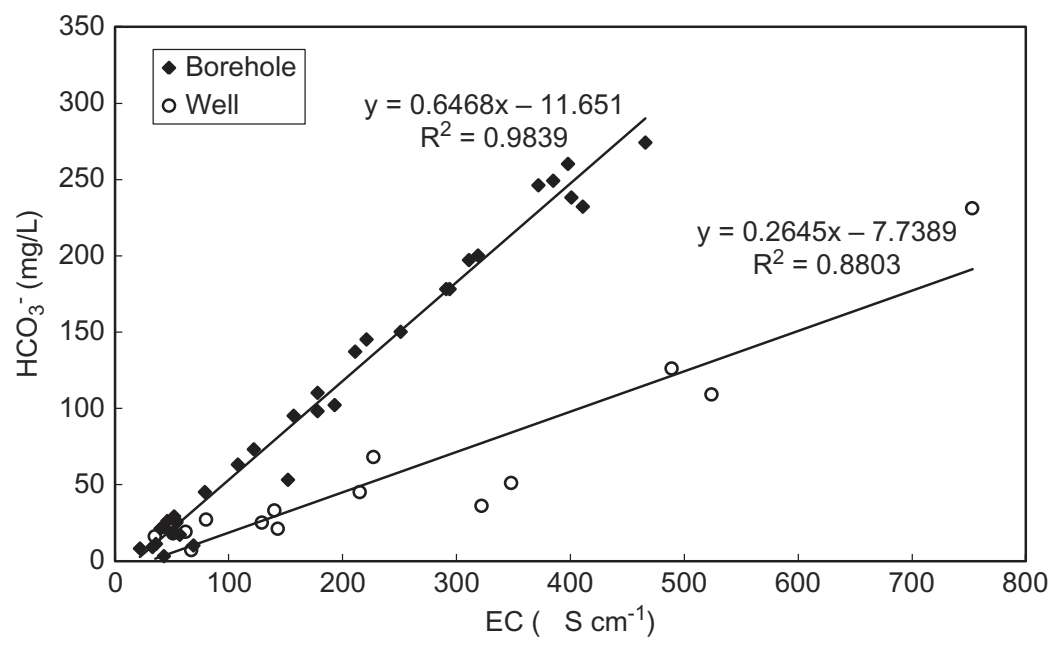

Fig. 6 Relationship between EC and bicarbonate concentrations for groundwaters of the Bangui region. Two very distinct tendencies can be identified for EC greater than $150 \mu \mathrm{S} \mathrm{cm}^{-1}$, reflecting the carbonate or non-carbonate type of the aquifers tapped.

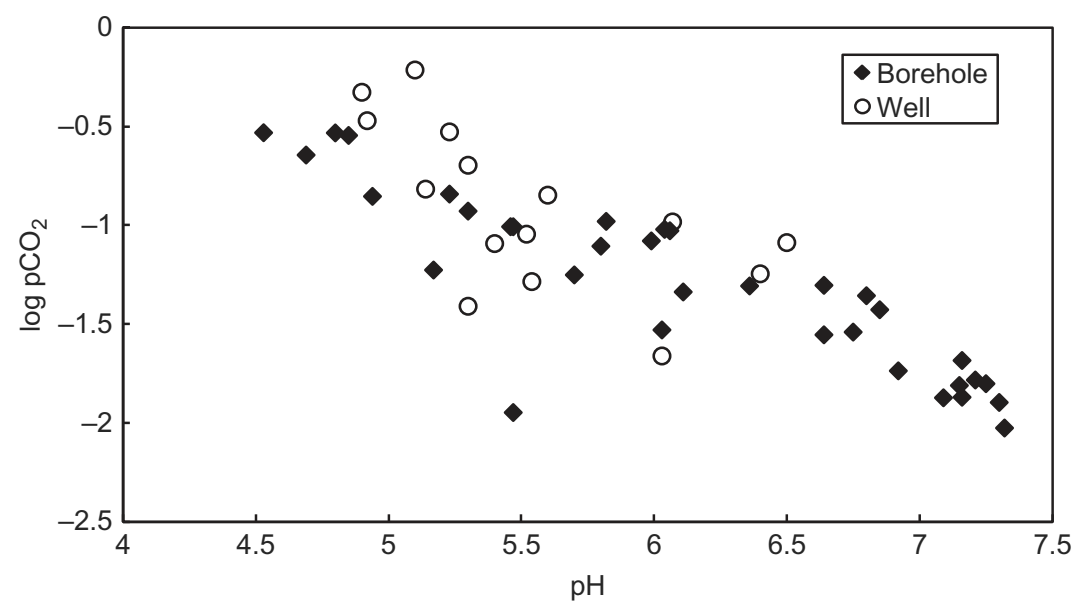

Fig. 7 Relationship of $\log \mathrm{pCO}_{2}$ to $\mathrm{pH}$ for groundwaters of the Bangui region.

remain unaffected by this pollution and display chloride concentrations in agreement with the rainfall input and water-rock interactions. There is no data for the Central African Republic concerning the rainfall input in terms of quality, but previous surveys in Central and West Africa have mentioned chloride concentrations varying from 0.18 to $2.31 \mathrm{mg} / \mathrm{L}$ for neighbouring northern Cameroon (Njitchoua et al. 1995), averaging $0.73 \mathrm{mg} / \mathrm{L}$ in Yaoundé (Fouépé Takounjou et al. 2010) and an annual weighted mean concentration of about $0.3 \mathrm{mg} / \mathrm{L}$ for Niger (GalyLacaux et al. 2009). This latter study also provides an annual weighted mean concentration of about $0.2 \mathrm{mg} / \mathrm{L}$ for sodium and about $0.3 \mathrm{mg} / \mathrm{L}$ for potassium in rainfall. The Bangui wells' concentrations are clearly higher than these values, even considering the evaporation conditions.
Correlations between chloride and the other elements of potential anthropogenic origin, such as sulphate and nitrate, are more complex. High sulphate concentrations are associated with high chloride concentrations in only four wells (W6, W7, W8, W12), with a maximum value of about $50 \mathrm{mg} / \mathrm{L}$. These correspond to specific point source pollution and are all located in the vicinity of possible sources. The boreholes do not show any elevated concentration in sulphate, which remains below $4 \mathrm{mg} / \mathrm{L}$. Nitrate contamination is very apparent in wells, and reaches $49 \mathrm{mg} / \mathrm{L}$, just below the drinking water standard (50 $\mathrm{mg} / \mathrm{L})$, but indicating serious organic pollution of the shallow aquifer, as commonly encountered in other big African cities (Nkotagu 1996, Nyenje et al. 2010, Yidana et al. 2010, Foster et al. 2011, Huneau et al. 2011). For instance in Cameroon, the cities of 



Fig. 8 Comparison of concentrations of dissolved calcium and magnesium as a function of bicarbonate concentration for groundwaters of the Bangui region.

Douala and Yaoundé both present nitrate pollution of the shallow groundwater resources, with maximum concentrations up to $100 \mathrm{mg} / \mathrm{L}$ that are always strongly correlated with faecal bacteria contamination (Zébazé Togouet et al. 2009, Takem et al. 2010).

No correlation is apparent in the chloride-nitrate graph, suggesting that these two pollutants are of different origin. The nitrate pollution appears to be diffuse, affecting all the sampled wells. The very poor sanitation conditions, the density of pit latrines and the existence of numerous organic waste dumps are responsible for this widespread contamination affecting the most superficial groundwater resources of Bangui, which unfortunately are the most used by the population.

\subsection{Point source pollution identified at the former UCATEX factory site}

As previously mentioned, specific point source pollution seems to affect only the wells in an area restricted to the southeast of Bangui airport. This pollution is particularly marked by high EC and high sulphate, potassium, chloride and sodium concentrations, far above the local baseline of the shallow groundwater. Even if organic contamination (shown by the nitrate concentration) is superposed, these high concentrations indicate another contamination source. From the field investigations, a former industrial site, locally known as the UCATEX factory (close to well W12), is suspected to be at the origin of the underground pollution. The UCATEX factory was used to produce textiles involving chemical dyeing processes. It appears that, since the cessation of the UCATEX activities in 1993, polluted industrial wastewaters stored and abandoned in settling tanks have infiltrated towards the water table and polluted the shallow aquifer. Considering the shallow groundwater flow direction (Fig. 1), a pollution plume is now developing towards the south and the Ubangi River. Wells W6, W7 and W8 are located on this groundwater flow direction and affected by the industrial pollution. Depending on the depth of the wells, the pollution is more or less developed and detectable in the groundwater quality. Nguimalet (2004) reports that, particularly in lowwater periods, the degradation of the water quality 

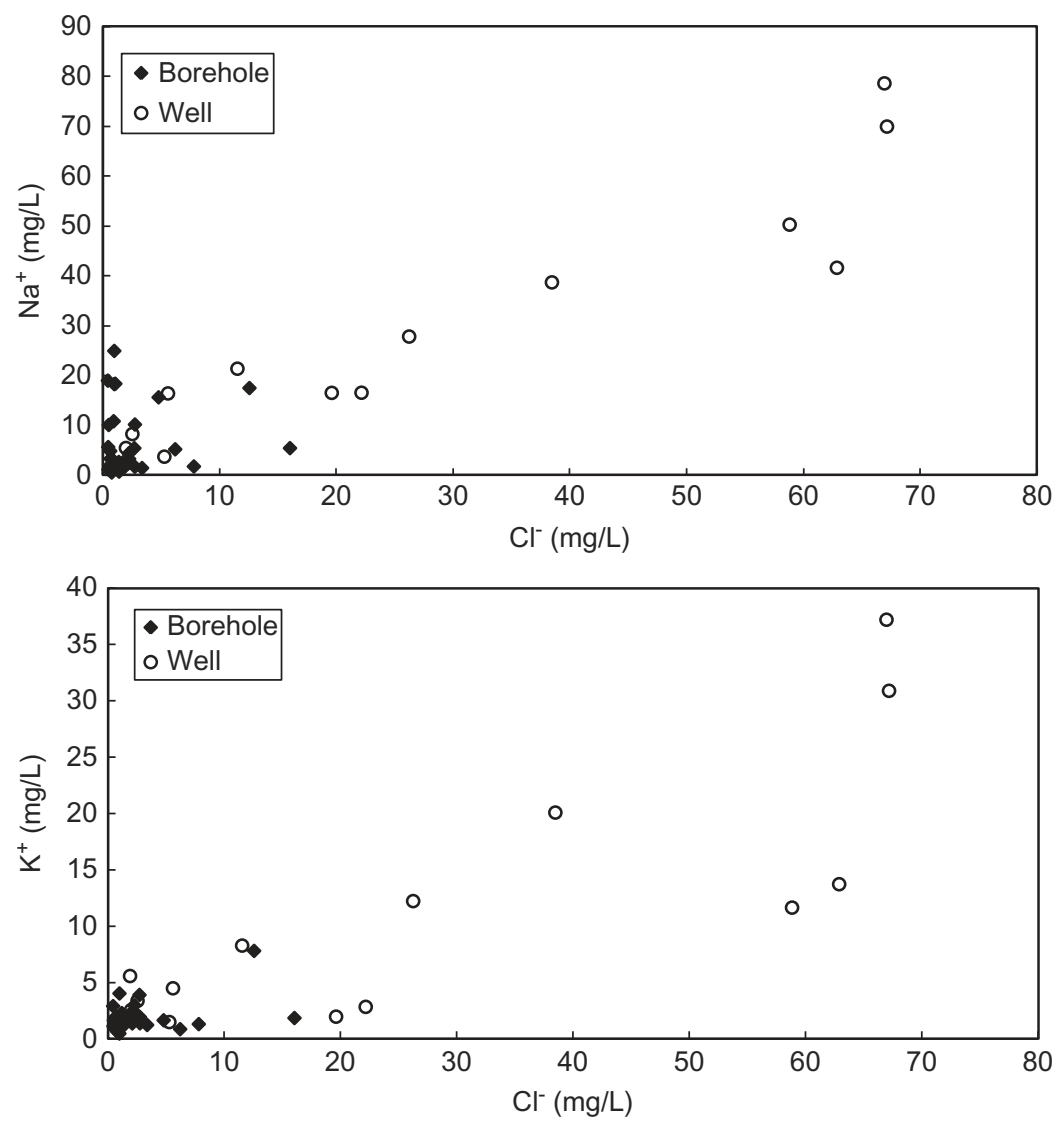

Fig. 9 Comparison of concentrations of dissolved sodium and potassium as a function of chloride concentration for groundwaters of the Bangui region.

dramatically increases (change of colour, bad smell) as a consequence of reduced dilution by rainwater infiltration. At present, no official measures are undertaken by the authorities to discourage people from using these contaminated wells. From our investigations, no propagation of the surface pollution around the UCATEX site can be detected in the deep aquifer, which in this area lies at approx. $150 \mathrm{~m}$ below the surface and can be considered as semi-confined under a discontinuous Tertiary clay lens of about $50 \mathrm{~m}$ thickness (Nguimalet 2004).

\subsection{Two main reservoirs and contrasting groundwater resources}

Figure 10 illustrates the different groundwater extraction conditions and structural contexts encountered in the Bangui city area, and the types of well/borehole. In Table 2, the sampled wells and boreholes are classed according to that typology:

1. borehole tapping the deep aquifer of the Bimbo limestone at shallow depth;
2. borehole tapping the shallow aquifer of the Tertiary deposits without touching the Precambrian limestone and sandstone;

3. shallow well restricted to the aquifer levels of the laterite developed on the Upper Tertiary and Quaternary deposits or the Archean quartzite and schist;

4. borehole tapping the deep aquifer of the Fatima limestone at various depths; and

5. borehole tapping the quartzite and schist of the flanks of the Bangui Hills.

From the previous comments and observations, it is apparent that the Bangui region is able to offer interesting groundwater resources to its developing population. The deep carbonate sediments lying under Bangui city are the priority groundwater resource to target. For the moment, these levels are only exploited marginally by boreholes in places where water can be accessed easily by the limited capacities of local drillers. As discussed previously, the complex palaeomorphology of the fractured and karstified limestone is difficult to understand, and the aquifer level is not 


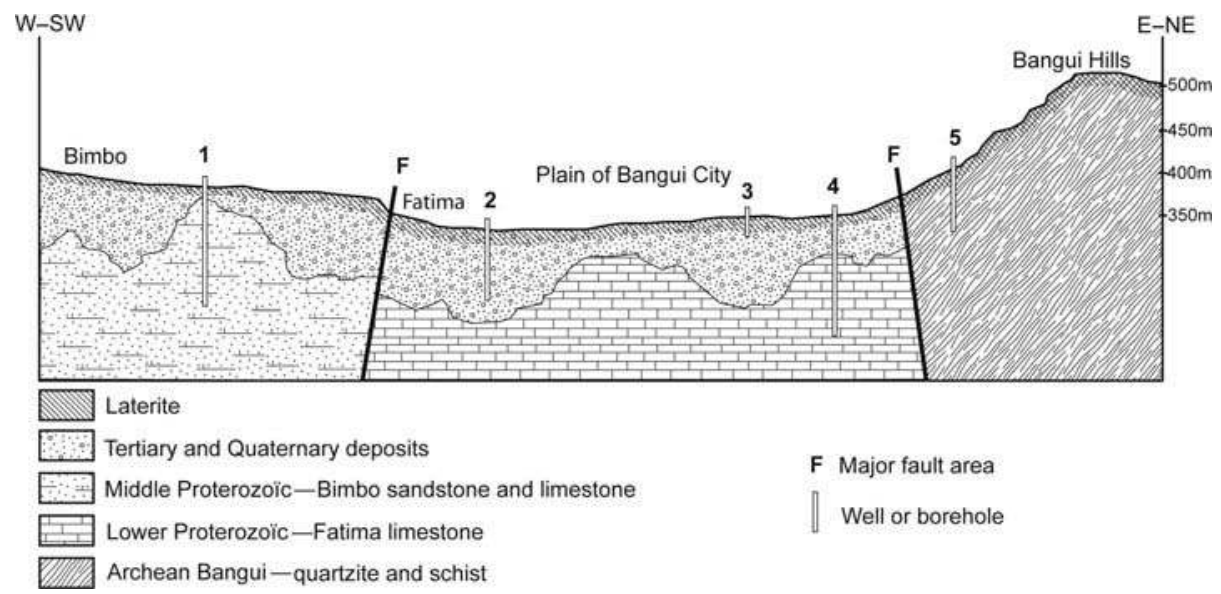

Fig. 10 Schematic interpretative geological cross-section through the Bangui city region and illustration of the different groundwater extraction structures encountered. Key: 1: borehole tapping the deep aquifer of the Bimbo limestone at shallow depth; 2: borehole tapping the shallow aquifer of the Tertiary deposits without reaching the Precambrian limestone and sandstone; 3: shallow well restricted to the aquifer levels of the laterite developed on the Upper Tertiary and Quaternary deposits or the Archean quartzite and schist; 4: borehole tapping the deep aquifer of the Fatima limestone at various depths; and 5: borehole tapping the quartzite and schist on the flank of the Bangui Hills.

always reached when an attempt is made. The quality of the deep limestone aquifer is relatively good considering the major ions, and is not affected by nitrate contamination. In some places, the deep carbonate aquifer is considered as semi-confined under the Tertiary deposit in which clay lenses act as lowpermeability interfaces. In terms of residence time, the quite elevated concentrations of $\mathrm{Mg}^{2+}$ registered in many samples confirm the dolomitic type of some aquifer levels, but also indicate a groundwater residence time long enough to dissolve dolomite, which is known to have slow dissolution kinetics (Appelo and Postma 2005) and, hence, provides a good residence time indicator (Huneau et al. 2001, Celle-Jeanton et al. 2003, 2009). The occurrence of karstic features within the carbonate substratum of Bangui should be considered more as palaeo-morphological remains sealed under the Tertiary cover and not as active karst conduits. In terms of relationships with the rivers, particularly the M'Poko River, no direct influence was noted and the geochemical characteristics of the M'Poko River are clearly different from those of the carbonate aquifer. The Ubangi River behaves as the main drainage axis in the region and is probably partly fed by the underground discharge of regional aquifers (Dupré et al. 1996, Nguimalet 2004, Runge and Nguimalet 2005, Doyemet 2006). It receives waters discharged from the carbonate aquifer.

The shallow groundwaters of the Tertiary and Quaternary deposits, as well as the laterite developed on them, all grouped as non-carbonate aquifer formations, appear to be very poor resources given the chemical parameters measured during this survey. The shallowness of the aquifer combined with the inadequate sanitation and waste management of the developing Bangui city are responsible for major nitrate contamination of the resource that seriously limits the potential use of the water as drinking water supply, especially for the young population. The identification of industrial point source pollution around the UCATEX factory site, and already well spread in the subsurface, should encourage the authorities to forbid the use of well water, at least from within an area defined around the polluted site and south along the groundwater flow downgradient. Given the activities carried out in the UCATEX factory during its operation, a detailed survey including evaluation of the trace metal concentrations in groundwater should be organized. The shallow groundwater is more sensitive to river water interactions, particularly along the banks of the Ubangi and M'Poko rivers, but the few water table pressure potentials measured by JICA (1999) and Doyemet (2006) suggest the influences are restricted to areas in the immediate vicinity of the water courses.

\subsection{Future investigations}

Usually, the deep carbonate Precambrian aquifer (Bimbo or Fatima formations) is tapped below the Tertiary cover of a few metres to more than $150 \mathrm{~m}$ thickness, but not always, which gives a random 
character to any hydrogeological prospecting in the area. This is difficult to cope with given the very limited funds allocated to water supply development in the Central African Republic. To improve the situation and be able to develop more accessible and sustainable facilities for the resource, different options can be proposed. The first would be better delineation of the Tertiary-covered carbonate levels of the Precambrian. For this, geophysical survey combined with detailed inter-borehole lithostratigraphic correlation should be undertaken. In addition, further geochemical surveys are required to appreciate in detail the geochemical evolution of groundwater along the major flow paths, to identify the recharge area of the aquifer and to characterize groundwater in terms of both origin and quality. In view of the known source of pollution at the surface, trace metals need to be carefully followed, and combined with isotope hydrology tools (stable isotopes of the water molecule ${ }^{18} \mathrm{O}$ and ${ }^{2} \mathrm{H}$, and also carbon isotopes ${ }^{13} \mathrm{C}$ and ${ }^{14} \mathrm{C}$, or even $\mathrm{CFC}$ gases) to evaluate the residence time of the groundwater. This approach should also combine a good definition of the potentiometric heads and be coupled with a vulnerability mapping strategy, as proposed by Robins et al. (2007).

\section{CONCLUSION}

From the results of this survey, the very first to focus on groundwater flow and quality in the Bangui city area, it appears that the only reliable and appropriate quality groundwater resource lies in the deep carbonate aquifers of the Precambrian. These very old formations are poorly known because of the lack of outcrops in the region, but also because of their very complex pseudo-karstic palaeo-morphology inherited from post-Precambrian erosion. In the long term, the water-supply question relates more to the conditions of the exploitation rather than the resource quality. As explained by Foster et al. (2011), in developing cities too much public water-supply abstraction is concentrated within urban municipal limits, leading to unstable cones of piezometric depression and causing secondary problems of induced pollution. For this reason, the development of the carbonate aquifer should be planned and organized in protected "external" municipal well fields according to the proposals of Foster et al. (2011). This is needed for Bangui, where the pollution pressure on shallow groundwater is absolutely out of control and where the development of mining activities greatly reduces the security of the current river intake from the Ubangi. The areas north and west of Bangui airport need to be prospected. These low population zones, located upstream from the main pollution sources, could be adequate for the development of new production boreholes, provided that the drilling would be able to reach the carbonate aquifer lying at 150-200 $\mathrm{m}$ depth.

Acknowledgements This work was supported by the French Embassy in the Central African Republic through the $\mathrm{PhD}$ fellowship of Ms Chantal-Laure Djebebe-Ndjiguim. The authors would like to thank the "Ministère des Mines, de l'Energie et de l'Hydraulique" of the Central African Republic and particularly Mr Salé Bako and Mr Sylvain Guébanda for having provided help and an off-road vehicle to organize the field activities and sampling.

\section{REFERENCES}

Alvarez, P., 1995. Evidence of a Neoproterozoïc carbonate ramp on the northern edge of the Central African craton: relation with Late Proterozoïc intracratonic troughs. Geologische Rundschau, 84, 636-648.

Alvarez, P., 1997. Morphologies karstiques et implications minières en République Centrafricaine. Journal of African Earth Sciences, 25, 293-305.

Appelo, C.A.J. and Postma, D., 2005. Geochemistry, groundwater and pollution. Leiden, The Netherlands: Balkema.

Boulvert, Y., 1976. Notice explicative de la carte pédologique de la République Centrafricaine, no. 64. Feuille de Bangui à 1/200 000. Paris: ORSTOM.

Boulvert, Y., 1996. Etude géomorphologique de la République Centrafricaine, Carte à 1/1000 000. Paris: ORSTOM, Notice explicative 110 .

Boulvert, Y. and Juberthie, C., 1998. République Centrafricaine. In: C. Juberthie and V. Decu, eds. Encyclopaedia biospeologica. Moulis: Société de Biospéologie, 1659-1668.

Boulvert, Y. and Salomon, J.N., 1988. Sur 1'existence de paléocrypto-karsts dans le basin de l'Oubangui (République Centrafricaine). Karstologia, 11-12, 37-48.

Celle-Jeanton, H., et al., 2003. Contribution of time tracers $\left(\mathrm{Mg}^{2+}\right.$, TOC, $\left.\delta^{13} \mathrm{C}_{\mathrm{TDIC}}, \mathrm{NO}_{3}{ }^{-}\right)$to understand the role of the unsaturated zone. A case study: karst aquifers in the Doubs valley, Eastern France. Geophysical Research Letters, 30 (6), 1322.

Celle-Jeanton, H., et al., 2009. Twenty years of groundwater evolution in the Triassic sandstone aquifer of Lorraine: impacts on baseline water quality. Applied Geochemistry, 24, 1198-1213.

Callede, J. and Arquisou, G., 1972. Données climatologiques recueillies à la station bioclimatologique de Bangui pendant la période 1963-1971. Cahiers ORSTOM, Séries Hydrologie, 9 (4), 3-26.

Chidambaram, S., et al., 2011. Significance of $\mathrm{pCO}_{2}$ values in determining carbonate chemistry in groundwater of Pondicherry region, India. Frontiers in Earth Science 5, 197-206.

Cornacchia, M., Detay, M., and Giorgi, L., 1990. Nouvelles données sur l'hydrogéologie centrafricaine. Hydrogéologie, 3, 165-181.

Cornacchia, M. and Giorgi, L., 1986. Les séries précambriennes d'origine sédimentaire et volcano-sédimentaire de la République Centrafricaine. Annals of the Royal Museum for Central Africa (Tervuren, Belgium), Ser. In-8, Sci. Geol. 93.

Cronin, A.A., et al., 2006. Monitoring source and domestic water quality in parallel with sanitary risk identification in Northern 
Mozambique to prioritise protection interventions. Journal of Water Health, 4, 333-345.

De Waele, J., et al., 2004. Urban waste landfill planning and karstic groundwater resources in developing countries: the example of Lusaka (Zambia). Journal of African Earth Sciences, 39, 501-508.

Djebebe-Ndjiguim, C.L., 2007. Application des modèles hydrogéochimiques sur le bassin versant de Bangui. Thesis (Master), Université Bangui, Central African Republic.

Doyemet, A., 2006. Le système aquifère de la région de Bangui (République Centrafricaine), conséquences des caractéristiques géologiques du socle sur la dynamique, les modalités de recharge et la qualité des eaux souterraines. Thesis (PhD), USTL University of Lille, France.

Dupré, B., et al., 1996. Major and trace elements of river-borne material: The Congo Basin. Geochimica et Cosmochimica Acta, 60 , 1301-1321.

Elbaz-Poulichet, F., et al., 2002. Major ion chemistry of groundwaters in the Continental Terminal water table of southwestern Niger (Africa). Applied Geochemistry, 17, 1343-1349.

Fantong, W.Y., et al., 2010. Hydrochemical and isotopic evidence of recharge, apparent age, and flow direction of groundwater in Mayo Tsanaga River Basin, Cameroon: bearings on contamination. Environmental Earth Sciences, 60, 107-120.

Foster, S.D., Hirata, R., and Howard, K.W.F., 2011. Groundwater use in developing cities: policy issues arising from current trends. Hydrogeology Journal, 19, 271-274.

Fouépé Takounjou, A., et al., 2010. Estimation of groundwater recharge of shallow aquifer on humid environment in Yaounde, Cameroon, using hybrid water-fluctuation and hydrochemistry methods. Environmental Earth Sciences, doi:10.1007/s12665010-0822-x

Galy-Lacaux, C., et al., 2009. Long term precipitation chemistry and wet deposition in a remote dry savanna site in Africa (Niger). Atmospheric Chemistry and Physics, 9, 1579-1595.

Huneau, F., Blavoux, B., and Bellion, Y., 2001. Differences between hydraulic and radiometric velocities of groundwaters in a deep aquifer: example of the Valréas Miocene aquifer (southeastern France). Comptes Rendus de l'Académie des Sciences, Serie IIA - Earth and Planetary Science, 33, 163-170.

Huneau, F., et al., 2011. Flow pattern and residence time of groundwater within the south-eastern Taoudeni sedimentary basin (Burkina Faso, Mali). Journal of Hydrology, 409, 423-439.

Jaunat, J., et al., 2012. Hydrochemical data and groundwater dating to infer differential flowpaths through weathered profiles of a fractured aquifer. Applied Geochemistry, 27, 2053-2067.

JICA, 1999. The study on groundwater development in Bangui City in the Central African Republic. Tokyo: JICA, Technical Report.

Jirakova, H., et al., 2009. Palaeorecharge conditions of the deep aquifers of the Northern Aquitaine region (France). Journal of Hydrology, 368, 1-16.

Jirakova, H., et al., 2010. Carbone isotopes to constrain the origin and circulation pattern of groundwater in the north-western part of the Bohemian Cretaceous Basin (Czech Republic). Applied Geochemistry, 25, 1265-1279.

Lutz, A., et al., 2009. Sustainability of groundwater in Mali, West Africa. Environmental Geology, 58, 1441-1450.

Mestraud, J.L., 1982. Géologie et ressources minérales de la République Centrafricaine. Etat des connaissances à la fin 1963. Orléans: Mémoirs de BRGM 60.

Nguimalet, C.R., 2004. Le cycle et la gestion de l'eau à Bangui (République Centrafricaine), approche hydromorphologique du site d'une capital africaine. Thesis $(\mathrm{PhD})$, University Lumière Lyon-2, France.

Nikiema, J., et al., 2010. Correlative and comparative characterization of main ion concentrations in laterite groundwater in semi-arid northern Burkina Faso. Environmental Earth Sciences, 61, $11-26$.

Njitchoua, R., et al., 1995. Oxygen-18, deuterium and chloride in precipitation from the Garoua region, Northern Cameroon: meteorological implications. Comptes Rendus de l'Académie des Sciences Paris, t. 321, série IIa, 853-860.

Nkotagu, H., 1996. Origins of high nitrate in groundwater in Tanzania. Journal of African Earth Sciences, 22, 471-478.

Nyenje, P.M., et al., 2010. Eutrophication and nutrient release in urban areas of sub-Saharan Africa-a review. Science of the Total Environment, 408, 447-455.

Parkhurst, D.L. and Appelo, C.A.J., 1999. User's guide to PHREEQC (version 2), a computer program for speciation, batch-reaction, one-dimensional transport, and inverse geochemical calculations. Denver: USGS, US Geological Survey Water-Resources Investigations Report 99-4259.

Plesinger, J., 1990. Les eaux souterraines de la République Centrafricaine et leur exploitation. Projet d'appui technique au programme d'hydraulique villageoise PNUD-Bangui. Bangui: PNUD, Technical Report.

Poidevin, J.L., 1976. Les formations du Précambrien supérieur de la Région de Bangui (République Centrafricaine). Bulletin Société Geologique France, 18, 999-1003.

Poidevin, J.L., 1996. Un segment proximal de rampe carbonate d'âge protérozoique supérieur au Nord du craton d'Afrique centrale (sud-est de la République Centrafricaine). Journal of African Earth Sciences, 23, 257-262.

Poidevin, J.L., 2007. Stratigraphie isotopique du strontium et datation des formations carbonatées et glaciogéniques néoprotérozoiques du Nord et de l'Ouest du craton du Congo. Comptes Rendus Geosciences, 339, 259-273.

Rakhmatullaev, S., et al., 2010. Groundwater resources and management in the Amu Darya River Basin (Central Asia). Environmental Earth Sciences, 59, 1183-1193.

Reimann, C. and de Caritat, P., 1998. Chemical elements in the environment. Berlin: Springer-Verlag.

Riou, C., 1972. Etude de l'évaporation en Afrique Centrale (Tchad, République Centrafricaine, Congo), contribution à la connaissance des climats. Thesis (PhD), University Paris VI, France.

Robins, N.S., Chilton, P.J., and Cobbing, J.E., 2007. Adapting existing experience with aquifer vulnerability and groundwater protection for Africa. Journal of African Earth Sciences, 47, 30-38.

Rolin, P., 1992. Nouvelles données tectoniques sur le socle précambrien de Centrafrique: implications géodynamiques. Comptes Rendus de l'Académie des Sciences, Paris, t. 315, série IIa, 467-470.

Runge, J. and Nguimalet, C.R., 2005. Physiogeographic features of the Oubangui catchment and environmental trends reflected in discharge and floods at Bangui 1911-1999, Central African Republic. Geomorphology, 70, 311-324.

Takem, G.E., et al., 2010. Pollution characteristics of alluvial groundwater from springs and bore wells in semi-urban informal settlements of Douala, Cameroon, Western Africa. Environmental Earth Sciences, 61, 287-298.

Tanawa, E., et al., 2002. Habitat and protection of water resources in suburban areas in African cities. Built Environment, 37, 269-275.

Wacrenier, P., 1960. Rapport de mission 1960 dans la coupure de Bangui Ouest. Arch. DGM RCA.

Yidana, S.M., Banoeng-Yakubo, B., and Akabzaa, T.M., 2010. Analysis of groundwater quality using multivariate and spatial analyses in the Keta basin, Ghana. Journal of African Earth Sciences, 58, 220-234.

Zébazé Togouet, S.H., et al., 2009. First data on the groundwater quality and aquatic fauna of some wells and springs from Yaoundé (Cameroon). European Journal of Water Quality, 40, 51-74. 